\title{
Using Japanese Capital to Invest in Vietnam Effectively and Some Solutions to Apply to Developing Countries
}

\author{
Dong Thi Thao NGUYEN ${ }^{1 *}$, Nguyen Tan DANH ${ }^{2}$, Huynh Tan $\mathrm{HOI}^{3}$ \\ ${ }^{1}$ Faculty of Business Administration, Ho Chi Minh City Open University, Vietnam, \\ Email:nguyen.43211010tpe2@oude.edu.vn \\ 2,3FPT University, Vietnam \\ * Corresponding Author
}

\begin{abstract}
Received: 09.11.2021
Accepted: 11.12.2021

Published: 01.02.2022

DOI: 10.47750/QAS/23.186.01
\end{abstract}

\begin{abstract}
ODA is an important source of capital for developing countries, including Vietnam. Currently, ODA has contributed to economic growth and poverty reduction, gradually bringing Vietnam into the club of low-middle-income countries. However, the use of ODA has been revealing many limitations, on the basis of pointing out the causes and inadequacies in the use of this capital in Vietnam over the past time, the article offers some basic solutions in order to increase the efficiency of using ODA capital in Vietnam in the coming time. The article uses current and previous research results, as well as survey results, and determines the importance of using this capital to gradually develop sustainably not only in Vietnam but also in other developing countries.
\end{abstract}

Keywords: Effectiveness, Japan, ODA, Vietnam, economy.

\section{Introduction}

Official Development Asisstance (ODA) is all nonrefundable, non-refundable, preferential credit from governmental organizations, intergovernmental organizations or non-governmental organizations. Government (NGO) or United Nations organizations and possibly international financial institutions for developing and underdeveloped countries (Kawasaki, 2004).

Japan's ODA has played a very important role in the economic development strategy; promoting agricultural and rural development. Through 20 years of cooperation receiving ODA investment from Japan (1993 to 2013), Vietnam has had many shortcomings such as wastefulness; formulating strategies and plans to attract and use ODA in irrational areas; Low level of management, lack of experience in the process of receiving, handling, operating projects ... makes the efficiency and quality of investment projects with this capital low, which can push ODA recipients like Vietnam. Nam into a state of debt (Kato, 2016).

\section{Status of ODA resources using}

In the period of 1993 up to now, Vietnam has had many social achievements in many different fields thanks to Japanese ODA capital.

Firstly, in terms of infrastructure, in the first phase of 2011, Japan's ODA to Vietnam reached 58.18 billion, the above credit source will directly go to two important transport infrastructure projects in Vietnam, the Construction Project. expressway HCMC - Long Thanh - Dau Giay (with total investment capital of 932.4 million USD, using official development assistance (ODA) capital of Japan and Asian Development Bank - ADB) and Da Nang - Quang Ngai Expressway Construction Project (total investment capital of 1,472 million USD, including ODA from Japan, World Bank (WB) and reciprocal capital of the Government of Vietnam (Kato, 2016).

In the first 6 months of 2013, these funds focused on infrastructure development with more than 1.4 billion USD, accounting for $37.37 \%$ with 3 large projects totaling more than 550 million USD, including building houses. Terminal T2 Noi Bai international airport, to expand Da Nhim hydroelectric plant, to build an viaduct from Mai Dich-Nam Thang Long section of belt 3 of Hanoi (Kato, 2016).

Some ODA projects of great value in 2013 must be mentioned as the centralized wastewater treatment plant in Yen Xa, Thanh Tri, Hanoi with over 306 million USD; Hanoi Urban Railway Construction Project Line 1 - Phase 1 (Ngoc Hoi Station) worth USD 179.2 million; The project to improve the safety of Hanoi - Ho Chi Minh City railway is more than 148 million USD (Ohno, 2007).

According to statistics of the Ministry of Transport, with a receiving size of approximately 80 billion yen in 2013, infrastructure continues to be the area receiving the most Japanese ODA in Vietnam.

In addition, agriculture and rural development are also greatly supported. Rural development is indispensable for Vietnam's sustainable growth. Agriculture is both an opportunity and a challenge for the economic development of Japan, that is, Japan's ODA has also continuously supported Vietnam in the agricultural sector (Ohno, 2007).

Vietnam is supported mainly in three areas: Improving income; as well as the farmer's life; Improving the agricultural 
education system in Vietnam; Marine development real estate in Vietnam (Hatakeyama, 2008).

To date, Japan has sponsored 70 projects with the total capital of 1.3 billion USD to the Agriculture and Rural Development sector. Of which, 60 projects are technical assistance projects, non-refundable aid, emergency assistance with a total capital of over 300 million USD, and 10 large loan projects in the field of irrigation and forestry with close 1 billion USD. Although ODA flows into agriculture are not much, but according to the assessment of the Ministry of Agriculture and Rural Development, this capital has contributed significantly to the development of the industry in recent years (Trinidad, 2007).

Tens of thousands of kilometers of rural roads have been improved and upgraded, 111 rural small bridges with a length of $25-100 \mathrm{~m} /$ bridge have been built, contributing to supporting agricultural development and improving an important step in people's lives. Remote and ethnic minority areas, especially in access to public services in the fields of health and education (Hirata, 2001).

In addition to these successes, there are still many issues that need to be considered such as improving the efficiency of ODA flows. One of the main reasons for the ineffective use of ODA is that awareness and understanding of the nature of ODA are not accurate and complete in the process of mobilizing and using (Furuoka, \& Iwao, 2008).

Perceptions that ODA is free and that the responsibility to repay ODA loans rests with the government. Such misperceptions have led to inefficiencies in the implementation of a number of ODA programs and projects (Hien, 2008).

Indeed, although most ODA is in the form of concessional loans with low interest rates, long repayment periods. ODA is not free and its use is a trade-off. If ODA is not used effectively, the debt repayment burden will increase. Not only that, due to the lack of management capacity, it leads to large losses. The organizational structure and staff capacity in ODA management and implementation are weak and have not met the requirements of improving ODA effectiveness (Hatakeyama, 2008).

According to Transparency International's corruption perception rankings published in September 2008, among 180 countries and territories, Vietnam ranked 12th1 (Trinidad, 2007).

The leakage and corruption in the PMU18 project, the major projects in the oil and gas sector, the $2008 \mathrm{PCl}$ bribery is a prime example of the limitations in ODA management and monitoring. The challenge of ensuring transparency and accountability in ODA management from the Vietnamese side is a critical issue (Kato, 2016).

The issue of Japan's ODA debt repayment should be raised from now on. In Vietnam, the mobilization of ODA only focuses on attracting more and more ODA with easy conditions, but resources and repayment capacity have not been given due attention (Hatakeyama, 2008).

Decentralization in the management and use of ODA has been implemented and has obtained important results such as expanding beneficiaries and enhancing autonomy of local governments. However, the decentralization of ODA has not met the requirements of reform in public resource management (Trinidad, 2007).

Decentralization policy in the management and use of ODA has not been consistent between the central and local levels. The limited capacity of local staff in professional expertise and foreign languages is also a factor limiting the decentralization and effective use of this capital. Poor coordination between central and local governments, local government and donors has resulted in delays in project design and implementation (Hatakeyama, 2008).

This situation also easily leads to inefficient and wasteful use of ODA. In order to improve the efficiency of ODA use, more investment is needed in building capacity for local management and administration. A typical example of the inefficient use of ODA funds in Ho Chi Minh City is the metro project line 1 (Ben Thanh - Suoi Tien). Ho Chi Minh City has difficulty in capital payment for the construction contractor for the above project. This affects the goal of completion by 2020 (Trinidad, 2007).

The arrangement of ODA capital plans for 2017 and the medium term for the period from 2016 to 2020 has not met the demand. Specifically, in 2017, the allocated ODA capital was only 2,119 billion VND while the demand was 5,422 billion VND (meeting 39\%), in the 2016-2020 period, the capital need was 20,930 billion VND, metro line 1 was assigned 7,500. VND billion (equivalent to $36 \%$ ). This metro route "capitalized" from 17,400 billion VND to more than 47,300 billion VND (increased by $87 \%$ ), Line 2 increased from 1,374 billion USD to 2,173 billion USD (58\% increase) but still behind schedule may be up to 4 years (Ohno, 2007).

Therefore, to ensure the construction progress of metro project No. 1, the City People's Committee has advanced the budget to pay the construction contractor. However, this is only a temporary solution.

\section{Research methods}

The research paper is based on articles and studies from highly reputable government newspapers and also data through the FPT University Ho Chi Minh University's individual survey with questions related to the current situation of resource use. Japan's ODA in Vietnam. Link to the survey is done online at https://forms.gle/uVC9NhfzxNMcMZuK9

In order to get the exact parameters, a three-question survey was conducted and the following responses were obtained with 64 participants: 


\section{GENERAL MANAGEMENT}

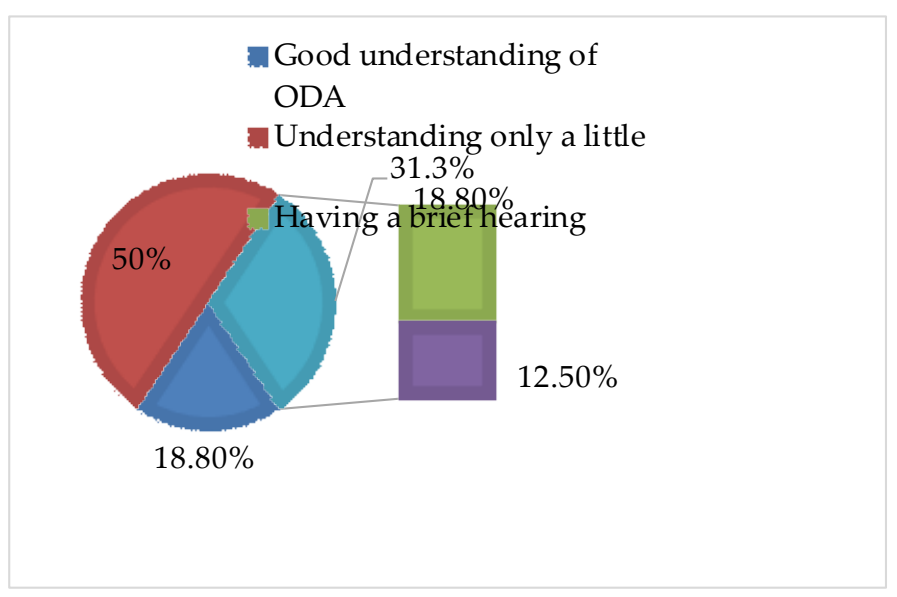

Figure 1: People's understanding of the concept of ODA

Through figure 1, we can see that the majority of respondents' understanding about ODA is quite vague and mainly knows ODA through websites and major events, so there are wrong perceptions about the current situation of ODA in Vietnam (Figure 1).

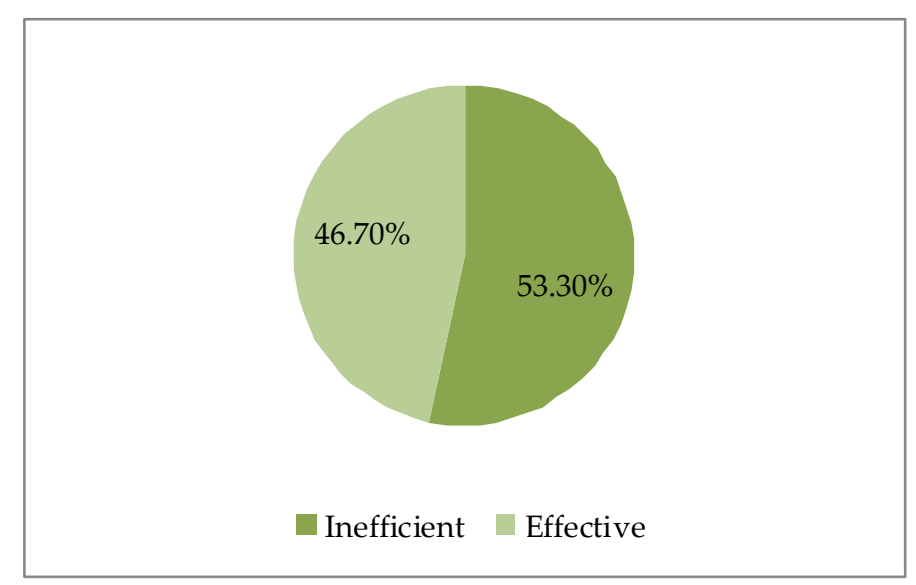

Figure 2: From a daily perspective, can you see that Vietnam is really effectively using ODA

Through figure 2, we can see that with daily observation without any research, the majority of people find that ODAfunded projects are ineffective. Typically, the perception of people about the Metro Line 1 project in the city. Ho Chi Minh City where the survey was taken.

\begin{tabular}{|l|}
\hline Answer 1: Clearly disclosing revenues and expenditures on projects (3 respondents with similar ideas) \\
\hline Answer 2: Pay the debt first, stop making people miserable \\
\hline Answer 3: Limit eating and eating less, then ODA will be very effective. \\
\hline Answer 4: Less corruption \\
\hline Answer 5: Used for the right purpose, the right amount of sponsored capital \\
\hline Answer 6: No bribery \\
\hline $\begin{array}{l}\text { Answer 8: In my opinion, even the use of governmental capital for investment is not scientific and } \\
\text { reasonable, not to mention ODA. I think the bottom line still lies in capital planning and corporate thinking. }\end{array}$ \\
\hline Answer 9: I don't know (there are 3 people with similar ideas) \\
\hline
\end{tabular}

Table 3: What can Vietnam do to use ODA from Japan more effectively? Please state your opinion

This question has 64 respondents and 2 questions overlap the meaning.

Through the three questions above, it can be seen that most of the survey participants know about ODA, but only a few understand its nature, but mainly know through network channels causing misunderstanding in the status of ODA in 
Vietnam (Araki, 2007)

Most people think that Vietnam is using ODA from Japan ineffective and that the main reason is due to corruption, but this is only from a small perspective, if we look closely, the ODA capital has brought. In return, Vietnam has many benefits, especially in the field of infrastructure, which was mentioned in the current situation (Ohno, 2007).

\section{Some recommendations}

Given the current situation of Vietnam, in order for the legal framework on ODA to be highly stable and able to adjust well in the management and use of ODA, a number of urgent requirements need to be met.

Strong enough sanctions must be established to increase accountability of investment decision-makers (Hoi, 2020). These sanctions must be clear to the following levels: People who decide to invest wrongly, cause waste, and losses must be handled at different levels depending on the degree of violation, can be administratively sanctioned, may be dismissed or dismissed; The investor must take comprehensive responsibility for the project efficiency and quality, put an end to the unqualified person to perform project management; Rearranging project management boards according to appropriate criteria and standards; (iv) The Investor is responsible for regularly inspecting and supervising the project management units, promptly detecting arising problems and proposing solutions.

Clearly defining responsibilities among the agencies in charge of making decisions on ODA management, should choose an agency with full responsibility from project preparation to stage, operation and exploitation of the project. Should establish an interdisciplinary organization tasked with synthesizing, analyzing information, assessing the situation in relation to macro indicators such as: national debt balance, government debt balance, product growth rate in country, import and export kimchos, balance of payments, and state budget deficit (Ohno, 2007).

Develop a strict working regulation of the project management board, have a clear and transparent operating budget and remuneration policy. At the same time, there is a strict reward and penalty regime: when the work is not lost,

\section{References}

[1] Ohno, I. (2007). Country-Specific Growth Support in East Asia and Africa-Japan's ODA to Vietnam and Ghana'. Tokyo: GRIPS.

[2] Trinidad, D. D. (2007). Japan's ODA at the Crossroads: Disbursement Patterns of Japan's Development Assistance to Southeast Asia. Asian Perspective, 31(2), 95-125. doi:10.1353/apr.2007.0019

[3] Hatakeyama, K. (2008). Japan's Aid to Vietnam: Becoming an Intellectual Leader?. Japanese Studies, 28(3), 345-364.

[4] Hien, P. T. (2008). The effects of ODA in infrastructure on FDI inflows in provinces of Vietnam, 2002-2004. In Vietnam Development Forum, Working Paper No. (89).

[5] Araki, M. (2007). Japan's official development assistance: The Japan ODA model that began life in Southeast Asia. Asia Pacific Review, 14(2), 17-29. meets the quality requirements, on schedule, the investor has a reward regime. On the contrary, through inspection and examination, if public servants or project management staff make mistakes, they will be strictly disciplined, in which the leaders must also bear joint responsibility (Trinidad, 2007).

\section{Conclusion}

Using ODA concessional loans must attach importance to economic efficiency, cannot use up all the available net income, and a part of the net income must be retained for timely repayment of capital and interest to ensure international prestige. Currently in Vietnam, for the economy to achieve broad results based on long-term foreign direct investment, improving infrastructure has become an urgent task. Therefore, in the early period of the industrialization and modernization, Vietnam needs to concentrate capital, especially ODA foreign concessional capital to invest in economic infrastructure construction projects, production establishments create many jobs and important investment projects of the State in each period.

\section{Ethical clearance}

We are ensuring the quality and integrity of our research. The ideas and opinions expressed in this paper are our effort. By writing this, we surely respect the confidentiality and anonymity of our research respondents since they participated in our study voluntarily.

\section{Conflict of interest}

No conflicts of interest noted.

\section{Acknowledgement}

We get financial support from our workplace and we would like to send our thanks to the place where we are working.

[6] Kawasaki, K. (2004). The Impact of Japanese Economic Cooperation on Asian Economic Development. Review of Urban and Regional Development Studies, 16(1), 14-32. doi:10.1111/j.1467-940x.2004.00078.x

[7] Hoi, H.T. (2020). The current status of learning Japanese online of Vietnamese students. International journal of scientific \& technology research. 9 (2), 1997-2001.

[8] Kato, H. (2016). Japan's ODA 1954-2014: Changes and Continuities in a Central Instrument in Japan's Foreign Policy. Japan's Development Assistance, 1-18. doi:10.1057/9781137505385 1

[9] Hoi, H. T. (2020). Advertising Vietnam's Tourism Products in the Technology Age. In Proceedings of the 2020 International Conference on Management of e-Commerce and eGovernment, 11-15.

[10] Hirata, K. (2001). Reaction and action: analyzing Japan's relations with the Socialist Republic of Vietnam. Japan and East Asian Regionalism, London: Routledge, 90-117.

[11] Furuoka, F., \& Iwao, K. A. T. O. (2008). The 'Honne--Tatemae' dimension in Japan's foreign aid policy: Overseas Development Aid allocations in Southeast Asia. Electronic Journal of Contemporary Japanese Studies, (6). 